\title{
Trace Elements in Frobisher Bay Rainwater
}

\author{
S.J. VERMETTE ${ }^{1}$ and V.G. BINGHAM ${ }^{1}$
}

(Received 27 March 1985; accepted in revised form 17 July 1985)

\begin{abstract}
Using short-decay instrumental neutron activation analysis, concentrations of the trace elements $\mathrm{Al}, \mathrm{Br}, \mathrm{Ca}, \mathrm{Cl}, \mathrm{Cu}, \mathrm{I}, \mathrm{Mg}, \mathrm{Mn}, \mathrm{Na}$, and $\mathrm{V}$ were determined in rainfall sampled from Frobisher Bay, N.W.T., during three weeks in the summer of 1984. Detectable concentrations were reported for all ten elements. Enrichment factors revealed that concentrations generally represent either crustal or oceanic natural background levels.

Key words: trace elements, precipitation, Arctic, Frobisher Bay

RÉSUMÉ. A l'aide de l'analyse par activation neutronique à décroissance courte, des concentrations des oligo-éléments $\mathrm{Al}, \mathrm{Br}, \mathrm{Ca}, \mathrm{Cl}, \mathrm{Cu}, \mathrm{I}, \mathrm{Mg}, \mathrm{Mn}$, $\mathrm{Na}$ et $\mathrm{V}$ furent décernés dans des échantillons d'eau de pluie à Frobisher Bay, aux T. N.-O., pendant trois semaines durant l'été de 1984. Ces dix éléments furent chacun représentés par des concentrations décelables. Des facteurs d'enrichissement signalèrent que les concentrations proviennent en général de sources naturelles océaniques ou de croûte terrestre.
\end{abstract}

Mots clés: oligo-éléments, précipitation, Arctique, Frobisher Bay

Traduit pour le journal par Maurice Guibord.

\section{INTRODUCTION}

The chemistry of atmospheric precipitation is of growing scientific concern. Aside from the elements that contribute to acid rain, there are numerous co-contaminants in precipitation, the concentrations and sources of which are not well understood.

Deposition by precipitation is a primary route by which atmospheric aerosols reach ground or water surfaces to interact with the ecosystem (Royal Society of Canada, 1985), yet there has been limited study of elemental composition of arctic precipitation (L.A. Barrie, pers. comm. 1985).

Precipitation is somewhat insensitive to the detection of atmospheric pollution as it generally discriminates against the fine particles containing the greatest pollution signal. The measurement of elemental concentrations in precipitation, however, is useful for the modeling of aerosol washout near the surface and the determination of elemental loadings to the environment during the arctic summer.

The sampling of atmospheric pollution has previously been confined to the filtering of aerosols and the sampling of snowpacks and ice cores (L.A. Barrie, pers. comm. 1985). Arctic aerosol studies confirm the existence of the polluting "arctic haze" in the winter and early spring months, while the summer months have generally been found to be unpolluted (Kerr, 1981; Barrie et al., 1981).

Concentrations during the summer months found to represent natural background levels serve as useful precursors to more detailed study and as useful comparisons to concentrations found during months of higher pollution levels.

The present research documents the concentrations and possible sources of ten trace elements in summer rains from Frobisher Bay, N.W.T. Precipitation was monitored for approximately three weeks 11 July-5 August 1984, and samples were collected during ten rain events. The very low detection limits and the precision of neutron activation analysis allowed determination of natural or anthropogenic (man-made) sources for elemental concentrations in rain samples.

\section{METHODOLOGY}

Due to the remoteness of the arctic study location, the use of either a bulk precipitation sampler, as described by Gambell and
Fisher (1966), or a Sangamo wet-only precipitation sampler was impractical. The intent was to remove the collector between precipitation events and thus sample only wet deposition. The precipitation sampler had to be easily transportable, nonmechanical and of simple but durable construction. To meet these requirements a modified bulk sampler was developed (Fig. 1).

Each bulk sampler consisted of a $500 \mathrm{ml}$ Nalgene polyethylene container inside a $1000 \mathrm{ml}$ container of similar composition. The large outer container had the upper portion cut off to allow positioning of the inner container. A $15 \mathrm{~cm}$ polyethylene funnel was positioned with the spout inside the mouth of the inner container. To avoid the necessity of washing the funnel and inner container following each collection, both were lined with replaceable polyethylene bags.

In order to avoid contaminating samples in the field, contact with the polyethylene bags and bottles was restricted to the outside surfaces only. All containers were sealed immediately upon removal from the sampler, and samples were transferred directly from the polyethylene bags to tightly capped storage containers immediately following the rain event. No bags were reused and all bottles were thoroughly cleaned, as prescribed by the Inland Waters Directorate (1983). Each storage bottle was preacidified with $2 \%$ nitric acid to limit the absorption of elements of interest to the walls of the storage bottle. Blanks with known concentrations of elements were stored $24 \mathrm{~h}$ in the polyethylene bags, and no significant contamination or absorption was found (Table 1). Precipitation samples stored in polyethylene bottles by the Great Lakes Institute have shown no decrease in elemental concentrations between subsequent analyses spaced several months apart (P. McQuarrie, pers. comm. 1984). Samples employed in this study were stored a few months prior to analysis, and caution was employed at all stages to avoid contamination (Bingham, 1984).

At the McMaster University swimming pool-type reactor, short-decay instrumental neutron activation analysis employing gamma spectroscopy was used on the precipitation samples for the simultaneous analysis of $\mathrm{Al}, \mathrm{Br}, \mathrm{Ca}, \mathrm{Cl}, \mathrm{Cu}, \mathrm{I}, \mathrm{Mg}, \mathrm{Mn}, \mathrm{Na}$, and $\mathrm{V}$. A wet sample was irradiated in a thermal neutron flux of $5 \times 10^{12} \mathrm{n} \mathrm{cm}^{2} \mathrm{sec}^{-1}$ for $10 \mathrm{~min}$. The irradiated sample was transferred to an inert vial and analyzed on a hyper-pure 


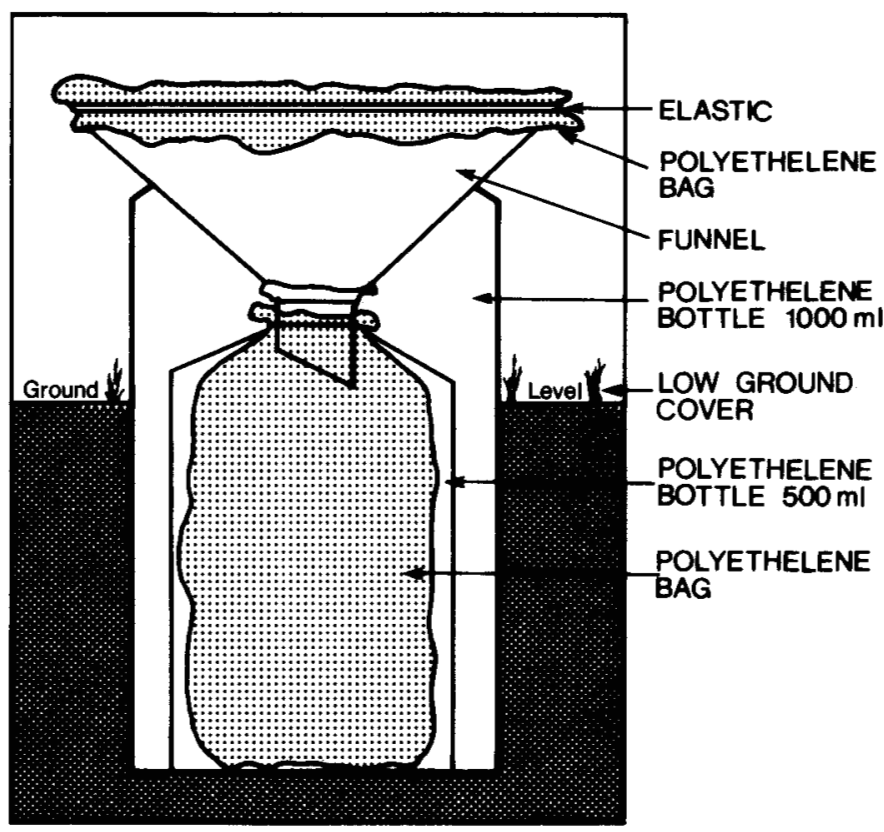

FIG. 1. Modified bulk sampler.

TABLE 1. Test results of contamination or absorption from polyethylene bags (ppb)

\begin{tabular}{lcc}
\hline \hline Element & $\begin{array}{c}\text { NBS 1643-b } \\
\text { (determined value) }^{1}\end{array}$ & $\begin{array}{c}\text { NBS 1643-b } \\
(24 \text { h in polyethylene bag) }\end{array}$ \\
\hline $\mathrm{Al}$ & $19+-2$ & $14+-2$ \\
$\mathrm{Br}$ & $<4$ & $<4$ \\
$\mathrm{Ca}$ & $39224+-2972$ & $40702+-2058$ \\
$\mathrm{Cl}$ & $5114+-229$ & $5422+-243$ \\
$\mathrm{Cu}$ & $20+-6$ & $22+-6$ \\
$\mathrm{I}$ & $<3$ & $<3$ \\
$\mathrm{Mg}$ & $8293+-732$ & $8547+-759$ \\
$\mathrm{Mn}$ & $32+-1$ & $33+-2$ \\
$\mathrm{Na}$ & $8844+-398$ & $9196+-414$ \\
$\mathrm{~V}$ & $48+-1$ & $50+-1$ \\
\hline \hline
\end{tabular}

${ }^{1}$ Averages and errors based on three determinations.

germanium counter. An average delay time of $90 \mathrm{~s}$ and a count time of $10 \mathrm{~min}$ gave optimum precision. Quality control was maintained with synthetic standards and the analysis of the National Bureau of Standards water standard (NBS 1643-a) with the rain samples.

\section{ANALYSIS AND DISCUSSION}

The concentrations of the trace elements for each precipitation event and average concentrations for the study period are shown in Table 2. Concentrations of $\mathrm{Ca}, \mathrm{Cl}, \mathrm{Mg}$, and $\mathrm{Na}$ are recorded by the Canadian Network for Sampling Precipitation (CANSAP) at selected arctic locations, and the concentrations reported here are in general agreement with 1977-81 arctic CANSAP data. The Frobisher Bay data most closely resemble data from Fort Chimo, which is the nearest arctic CANSAP site.

To differentiate between natural and anthropogenic (manmade) sources of trace elements, enrichment factors (EF) were calculated as follows:

$$
\mathrm{EF}(\text { crust or ocean })=\frac{(\mathrm{E} 1 / \mathrm{RE} 1)}{(\mathrm{E} 2 / \mathrm{RE} 2)} \text { in precipitation }
$$

The enrichment factors were normalized to $\mathrm{Al}$ for crustal sources and to $\mathrm{Na}$ for ocean sources. The ratio between the concentration of an element $(\mathrm{E} 1)$ in rainfall and that of one of the two reference elements (RE1 - $\mathrm{Al}$ or $\mathrm{Na}$ ) in rainfall was compared to the concentration ratio between the same elements in the crust or ocean (E2/RE2). If the ratios are the same, they give an enrichment factor of one, and this is referred to as unity. Values close to unity for the crustal enrichment factor indicate a probable crustal source, and similarly values close to unity for the ocean enrichment factor indicate a probable ocean source. Enrichment factors greater than one and that cannot be explained by either of the natural sources are a general indication of anthropogenic sources (Rahn, 1976).

As shown in Table 3, crustal enrichment factors for $\mathrm{Ca}, \mathrm{Mg}$, $\mathrm{Mn}$, and $\mathrm{V}$ approach unity and are supportive of crustal weathering as a source. This hypothesis is further supported by strong to moderate correlation coefficients between $\mathrm{Al}$ and $\mathrm{Mg}, \mathrm{Mn}$, and $\mathrm{V}(0.94,0.88$, and 0.63 respectively), which suggest a common source for these elements. Ocean enrichment factors for $\mathrm{Br}$ and $\mathrm{Cl}$ approach unity (Table 4) and indicate a possible ocean source. Correlation coefficients between $\mathrm{Na}$ and $\mathrm{Br}$ and between $\mathrm{Na}$ and $\mathrm{Cl}(0.90$ and 0.98$)$ are also indicative of a common source for these elements. The element $\mathrm{Ca}$, although not enriched and appearing to be derived from crustal weathering, is correlated quite strongly with $\mathrm{Na}(0.83)$ and the other elements hypothesized as being from ocean sources.

The greatly enriched values of I are in agreement with the results of previous studies (Seto and Duce, 1972; Cicerone, 1981). This I enrichment is not hypothesized as anthropogenic but as preferential enrichment from the oceans. All study elements appear to represent natural background levels with the exception of $\mathrm{Cu}$, which is enriched. A number of the $\mathrm{Cu}$

TABLE 2. Concentration of select trace elements in Frobisher Bay rainwater (ppb)

\begin{tabular}{|c|c|c|c|c|c|c|c|c|c|c|}
\hline Dates & $\mathrm{Al}$ & $\mathrm{Br}$ & $\mathrm{Ca}$ & $\mathrm{Cl}$ & $\mathrm{Cu}$ & I & $\mathbf{M g}$ & Mn & $\mathrm{Na}$ & V \\
\hline Jul 18-19/84 & 1300 & 10 & 1600 & 1300 & 24 & 14 & 800 & 25 & 1200 & 2 \\
\hline Jul 19-20/84 & 770 & 6 & 490 & 360 & $<12$ & 30 & 300 & 13 & 400 & 1 \\
\hline Jul 21-22/84 & 690 & 4 & 570 & 220 & 13 & 36 & 340 & 10 & 280 & 1 \\
\hline Jul 27/84 & 1000 & 7 & 1200 & 840 & $<14$ & 29 & 530 & 18 & 700 & 2 \\
\hline Jul 28-29/84 & 240 & 4 & 380 & 340 & $<9$ & 28 & 39 & 6 & 270 & 0.4 \\
\hline Jul 30-31/84 & 150 & 8 & 1400 & 1900 & 30 & 14 & 140 & 8 & 1300 & 0.4 \\
\hline Jul 31-Aug 1/84 & 1100 & 10 & 880 & 1100 & 18 & 29 & 450 & 15 & 1000 & 1 \\
\hline Aug 1-2/84 & 850 & 13 & 1900 & 3800 & 77 & 26 & 600 & 22 & 2400 & 3 \\
\hline Aug 3-4/84 & 1300 & 8 & 760 & 1300 & $<15$ & 22 & 670 & 18 & 1000 & 1 \\
\hline Aug 4-5/84 & 250 & 7 & 600 & 1700 & $<11$ & 30 & 66 & 7 & 1100 & 0.4 \\
\hline Average & 760 & 8 & 970 & 1300 & 19 & 26 & 400 & 14 & 1000 & 1 \\
\hline
\end{tabular}


TABLE 3. Crustal enrichment factors of Frobisher Bay rainwater normalized to aluminum (Wedepohl, 1971)

\begin{tabular}{|c|c|c|c|c|c|c|c|c|c|c|}
\hline Dates & Al & $\mathrm{Br}$ & $\mathrm{Ca}$ & $\mathrm{Cl}$ & $\mathrm{Cu}$ & I & $\mathrm{Mg}$ & $\mathrm{Mn}$ & $\mathrm{Na}$ & V \\
\hline Jul $18-19 / 84$ & $=1$ & 210 & 3 & 240 & 48 & 1700 & 3 & 2 & 3 & 1 \\
\hline Jul $19-20 / 84$ & 1 & 200 & 2 & 120 & $<13$ & 6000 & 2 & 2 & 2 & 1 \\
\hline Jul $21-22 / 84$ & 1 & 140 & 2 & 78 & 49 & 8300 & 3 & 2 & 1 & 1 \\
\hline Jul 27/84 & 1 & 190 & 3 & 200 & $<32$ & 4400 & 3 & 2 & 2 & 1 \\
\hline Jul 28-29/84 & 1 & 400 & 4 & 350 & $<13$ & 18000 & 1 & 3 & 4 & 1 \\
\hline Jul $30-31 / 84$ & 1 & 1400 & 26 & 3200 & 530 & 15000 & 6 & 6 & 28 & 2 \\
\hline Jul 31-Aug 1/84 & 1 & 260 & 2 & 250 & 43 & 4200 & 2 & 2 & 3 & 1 \\
\hline Aug $1-2 / 84$ & 1 & 410 & 6 & 1100 & 240 & 4700 & 4 & 3 & 9 & 3 \\
\hline Aug 3-4/84 & 1 & 170 & 2 & 240 & $<20$ & 2700 & 3 & 2 & 3 & 1 \\
\hline Aug 4-5/84 & 1 & 770 & 7 & 1700 & $<47$ & 19000 & 2 & 3 & 14 & 1 \\
\hline Average & 1 & 280 & 3 & 410 & 65 & 5300 & 3 & 2 & 4 & 1 \\
\hline
\end{tabular}

TABLE 4. Ocean enrichment factors of Frobisher Bay rainwater normalized to sodium (Bowen, 1966)

\begin{tabular}{|c|c|c|c|c|c|c|c|c|c|c|}
\hline Dates & Al & $\mathrm{Br}$ & $\mathrm{Ca}$ & $\mathrm{Cl}$ & $\mathrm{Cu}$ & I & $\mathrm{Mg}$ & $\mathrm{Mn}$ & $\mathrm{Na}$ & V \\
\hline Jul 18-19/84 & 1100000 & 1 & 33 & 1 & 69000 & 2000 & 5 & 110000 & $=1$ & 6800 \\
\hline Jul $19-20 / 84$ & 2000000 & 2 & 31 & 1 & $<34000$ & 13000 & 6 & 160000 & 1 & 10000 \\
\hline Jul 21-22/84 & 2500000 & 2 & 52 & 1 & 160000 & 22000 & 9 & 190000 & 1 & 22000 \\
\hline Jul $27 / 84$ & 1500000 & 2 & 46 & 1 & $<64000$ & 7200 & 6 & 130000 & 1 & 14000 \\
\hline Jul 28-29/84 & 930000 & 2 & 37 & 1 & $<16000$ & 18000 & 1 & 120000 & 1 & 7800 \\
\hline Jul $30-31 / 84$ & 120000 & 1 & 28 & 1 & 81000 & 1800 & 1 & 30000 & 1 & 1600 \\
\hline Jul 31-Aug 1/84 & 1100000 & 2 & 23 & 1 & 62000 & 5100 & 4 & 82000 & 1 & 7400 \\
\hline Aug 1-2/84 & 380000 & 1 & 21 & 1 & 110000 & 1900 & 2 & 48000 & 1 & 6400 \\
\hline Aug 3-4/84 & 1300000 & 1 & 19 & 1 & $<35000$ & 3700 & 5 & 90000 & 1 & 6200 \\
\hline Aug 4-5/84 & 240000 & $i$ & 14 & i & $<14000$ & 4700 & 1 & 34000 & 1 & 1900 \\
\hline Average & 830000 & 1 & 26 & 1 & 69000 & 4700 & 3 & 76000 & 1 & 5400 \\
\hline
\end{tabular}

concentrations were below or near detection limits and thus are reported here with caution. However Zoller et al. (1974) have reported enriched $\mathrm{Cu}$ concentrations in Antarctic aerosols and hypothesized a correlation between high enrichment and high volatility.

Enrichments for individual elements vary from date to date, but $\mathrm{Cu}$ and I enrichment increases and $\mathrm{Mg}, \mathrm{Mn}$, and $\mathrm{Ca}$ become slightly enriched on particular dates, most notably 30-31 July 1984. These increases in enrichment appear to be related to the development of a deep stationary low over southern Baffin Island, which drew air from more southerly regions of North America. It is possible that this air mass carried enriched concentrations of these elements from southern industrial sources.

\section{CONCLUSION}

During the three weeks in which rainfall was sampled at Frobisher Bay, the ten targeted trace elements were detected with a wide range of concentrations between sampling dates. These concentrations have been determined to generally represent either natural crustal or oceanic background levels and therefore are not of anthropogenic origin.

Instrumental neutron activation analysis has been shown to be a useful method for determining extremely low elemental concentrations in arctic precipitation.

\section{ACKNOWLEDGEMENTS}

The authors wish to thank the staff of the McMaster Reactor and the assistance given by Dr. Drake, Dr. Landsberger, and Anita Simsons.
The second author thanks the Department of Indian Affairs and Northern Development for field research grants.

\section{REFERENCES}

BARRIE, L.A., HOFF, R.M., and DAGGUPATY, S.M. 1981. The influence of mid-latitude pollution sources on haze in the Canadian Arctic. Atmospheric Environment 15(8):1407-1419.

BINGHAM, V.G. 1984. Lead and cadmium in precipitation: A comparison of urban and rural Essex County and Baffin Island. Unpubl. B.A. thesis, Department of Geography, University of Windsor, Windsor, Ontario.

BOWEN, H.J. 1966. Trace Elements in Biochemistry. London: Academic Press. $241 \mathrm{p}$.

CICERONE, R.J. 1981. Halogens in the atmosphere. Reviews of Geophysics and Space Physics 19(1):123-139.

GAMBELL, A.W., and FISHER, D.W. 1966. Chemical composition of rainfall in eastern North Carolina and Southeastern Virginia. Geological Survey Water Supply Paper 1535-k, Washington D.C. 41 p.

INLAND WATERS DIRECTORATE. 1983. Sampling for Water Quality. Ottawa: Environment Canada, Water Quality Branch. $55 \mathrm{p}$.

KERR, R.A. 1981. Pollution of the Arctic atmosphere confirmed. Science 212(4498):1013-1014.

RAHN, K.A. 1976. The Chemical Composition of the Atmospheric Aerosol. Technical Report, Graduate School of Oceanography, University of Rhode Island, Kingston, Rhode Island. 265 p.

ROYAL SOCIETY OF CANADA. 1985. Acid Deposition: Effects on Geochemical Cycling and Biological Availability of Trace Elements. Washington, D.C.: National Academy Press. 83 p.

SETO, F.Y., and DUCE, R.A. 1972. A laboratory study of iodine enrichment on atmospheric sea-salt particles produced by bubbles. Journal of Geophysical Research 77(27):5339-5349.

WEDEPOHL, K.H. 1971. Geochemistry. New York: Holt, Rinehart, and Winston Inc. $65 \mathrm{p}$.

ZOLLER, W.H., GLADNEY, E.S., and DUCE, R.A. 1974. Atmospheric concentrations and sources of trace metals at the South Pole, Science 183:198-200. 